\title{
Feminist geographies in Aotearoa New Zealand: Cultural, social and political moments
}

Women and Gender in Geography Research Network, Adams-Hutcheson G, Bartos AE, Dombroski K, Le Heron E, Underhill-Sem Y

Gender, Place and Culture 26(7-9):1182-1197 01 Jan 2019

Place, culture and time are significant in our gendered experiences as teachers and scholars of feminist geography. Our context is complex, situated, sometimes joyful and sometimes hurtful, but also intriguing and exciting. Aotearoa New Zealand is a nation of promise, potential and enigma: it was the first country in the world where women gained the vote in 1893 and now boasts the youngest woman world leader in 2017. It is also a postcolonial nation where structural racism, homophobia, and sexism persist, yet it also has given legal personhood to a river. During the 2017 national election a young Pākēha (New Zealander of European descent) woman lead her party to victory while a young Māori (Indigenous New Zealander) woman was ousted as head of her political party. The former secured the leadership of her party six weeks out from election day; the latter became a spokeswoman and advocate for those negotiating the intersections of poverty, motherhood and ethnicity. In this Country Report, we reflect on our current political and cultural context to highlight some of the common themes Aotearoa New Zealand-based feminist geographers have been exploring in research, teaching and praxis.

We have published this piece as a network of feminist geographers, the Women and Gender Geographies Research Network (WGGRN), which is an alliance of people who learn, teach and research gender in geography and related disciplines throughout the country. We have embraced this acronym to express the collective nature of the knowledge making process. In writing this piece, our preference was to not italicise words from te reo Māori (the Māori language) that are 
in common usage in Aotearoa New Zealand, where Māori is an official language. However, we were encouraged to assist the international readership of the Journal and use italics for Māori words commonly understood in Aotearoa New Zealand. We were swayed by this point although we acknowledge that using italics challenges our shared political commitment to give equal voice to the indigenous people of Aotearoa New Zealand.

Robyn Longhurst and Lynda Johnston (2015) provide an insightful and comprehensive analysis of the state of feminist geography in the country. In this article we take a different approach. Working with the notion of 'feminist moments' as significant moments in time that reveal the need for feminism, we provide examples of how key concerns remain important for feminist geographers research in Aotearoa New Zealand in 2017.

\section{First Moment: Geopolitics of Representation and Recognition}

Women suffragettes in Aotearoa New Zealand secured the right to vote in 1893 and fought for equal political rights for women, and, notably, for the prohibition of alcohol. These political and moral links are evident in 2017 General Election, as we discuss below (Pihama 2017; Scott 2017). Only three Prime Ministers since 1893 have been women, the latest elected as recently as October 2017. Jacinda Ardern, the New Zealand Labour Party leader, became the 40th Prime Minister of Aotearoa New Zealand, taking office at the age of 37. Under a mixed-member proportional representation system, she was able to form a coalition with the more left-leaning Green Party and the more right-leaning New Zealand First Party. Her 20-person cabinet included the largest ever number of women: four Pākēha women, two Pacific women and one Māori woman. 
But the dark side of this election was the story of Metiria Turei, the co-leader of the Green Party. After a substantial political career, Metiria Turei resigned from the co-leader position amid a political and moral controversy after coming out in solidarity with people on government benefits: she admitted to lying when she was young mother in order to receive higher social welfare payments. The vitriolic outpouring underscored that a greater standard of morality is required of Māori, and that when they are poor they must not only be deserving, but the most deserving of all. Despite Prime Minister Ardern's commitment to bringing in a government of 'kindness', a vocal unkindness is directed towards (ex) welfare recipients, refugees and people of colour. At the heart of this contradiction is the 'New Zealand experiment' (Kelsey 1997; Larner 2000), which is largely responsible for transforming Aotearoa New Zealand from a welfare to a neoliberal state beginning in the 1980s. In addition to prioritizing private economic interests and profits, the New Zealand experiment constrained access to social benefits and heralded the importance of paid work to good citizenship. However, important scholarship in New Zealand troubles unitary notions of neoliberalism as demonstrated through transformations within the Māori economy (Underhill-Sem and Lewis 2008; see also Bargh 2011; Bargh and Otter 2009) and within diverse and relational economies throughout Aotearoa New Zealand (Diprose, Thomas and Bond 2016; Diprose et al. 2017; Higgins and Larner 2017; Thomas 2015; Thomas and Bond 2016).

The politics of representation in the world of geography and higher education is also relevant at this moment. Feminist and queer geography is taught at some Aotearoa New Zealand universities (Johnston and Longhurst 2008, Longhurst and Johnston 2015), but women academics are underrepresented in geography departments, particularly at more senior positions. Despite a 
number of award-winning feminist geographers now holding senior leadership roles, including Waikato University | Te Whare Wānanga o Waikato Professors Robyn Longhurst as Deputy Vice-Chancellor Academic and Lynda Johnston as Associate Dean Academic and Deputy Dean of the Faculty of Arts and Social Sciences, and Professor Wendy Larner as Provost at Victoria University of Wellington | Te Whare Wānanga o Te Ūpoko o Te Ika a Māui and President of The Royal Society of New Zealand (since 2018), they are often rendered invisible in the wider geography narrative. For example, at the opening keynote address at the 2016 New Zealand Geography Society conference, the overview of the discipline in our country did not mention any women geographers. At the same conference the $M \bar{a}$ te Wā Māori Geographies session was placed in the very last timeslot - unfitting for tangata whenua (people of the land), the first peoples of our nation. What this means is that a politics of visibility and representation is still an ongoing issue in geographic knowledge-making in our country. We note, however, the successful stream on Gender, Sex, Place and Space (Watkins and Fisher 2016), the generative panel discussion “Gendered Geographies and Academic Work” (Davies et al. 2016), and the welcome presence of parent-geographers with babies in arms. We also note that other key conferences attended and organised by geographers have had better outcomes: the annual Social Movements, Resistance and Social Change conference has a strong indigenous presence, and the Aotearoa New Zealand Development Studies Network goes beyond the white male dominance of the geographical society meetings. Partly in response to commentary by our collective, two of the four keynotes of the 2018 New Zealand Geographical Society and Institute of Australian Geographers conference were by feminist geographers from Aotearoa and the opening keynote was on transgender lives in Aotearoa New Zealand.

\section{Second moment: Politics of Care-Labour and Bodies}


The personal is indeed political, and this is the crux of much feminist organising and thought. At the centre of this place-based organising is the fact that gendered and sexed bodies are always 'somewhere', and small, ubiquitous changes can transform such places (Gibson-Graham 2005; Dombroski 2016a; The SIGJ2 Collective 2012; The Tim-adical Collective 2017; Underhill-Sem 2005). The personal is always deeply embodied and emplaced, as queer and feminist activists attest. Within hours of taking leadership of the Labour Party, Jacinda Ardern was publicly asked about her plans for having children. This story continued to unfold as Ardern became Prime Minister and soon after announced her pregnancy. She gave birth in 2018, took 6 weeks maternity leave, then returned full-time to work as her partner took up full-time childcare. Recent class action on pay inequality evident in the on-going gender pay-gap has opened up discussion not just about equality in the workplace, but the care-work that women are often still performing at higher rates than men (Dombroski 2018). As of writing, a new and emerging politics of the body plays out in the parliament of our new government: babies are being held and breastfed in the house, and their gurgles and cries are audible as the bill extending paid parental leave from 18 to 26 weeks is passed (Bracewell-Worrall 2017).

Articulating a politics of the body is a topic familiar to feminist geographers in Aotearoa New Zealand given the early work of Robyn Longhurst (2001) on bodies and Lynda Johnston (2005) on queer geographies (Johnston 2017, 2018). Different bodies are recognised as being enmeshed in different power relations and much of our research seeks to untangle these (Johnston and Longhurst 2010; Longhurst and Johnston 2014). A number of examples come to mind: Yvonne Underhill-Sem (2001, 2003, 2005, 2015, 2016; Underhill-Sem and Sem 2015) draws attention to marked bodies in marginalised places outside Aotearoa and in the process extends the boundaries 
of feminist geography into the Pacific (see also Burry and Stupples 2017, on sex work as body work, body work and agency in Vanuatu). Kelly Dombroski (2011, 2016a, 2016b, 2018;

Dombroski McKinnon and Healy 2016; Dombroski et al. 2018) investigates the intersection between feminist geographies of the body, community economies, and diverse practices of care, mothering, birthing and activism. Sunita Basnet (2016) examines the embodied practices of teenage Bhutanese refugee girls and their mothers as they negotiate conflicting Butanese and 'Kiwi' cultural values, particularly as pertains to sex. Longhurst, Ho and Johnston (2008) bring attention to the body as a "research instrument" that validates the importance of building connections, solidarity and community building as feminist researchers. Sara Kindon (2016a, 2016b) problematises which bodies are normalised in participatory video research. Ann Bartos (2017) explores the embodied consequences of thinking, learning, and being in the body when confronted with intellectual challenges, bringing attention to the embodiment of knowledge production.

Beyond the politics of the body and into the related feminist ethic of care, we find inspiration in the work of Naomi Simmonds (2011), as she explores her heritage through her work on Māori women's discourses and approaches, known as mana wahine (Māori women's power and authority), highlighting new temporal dimensions of maternities. Gradon Diprose explores feminist ethics of care in community economies and activist groups (2015, 2016, 2017; Diprose et al. 2017a), Ann Bartos (2012, 2013; Kallio and Bartos 2017) prioritizes children as legitimate caring agents, Gail Adams-Hutcheson (2015, 2017a, 2017b, 2017c, 2018; Adams-Hutcheson and Longhurst 2017; Hutcheson 2013) engages with feminist methods, trauma geographies, bodies, disasters and affect, and Emma Sharp (2018) focusses on care-full food politics. Additionally, a 
number of collectives with members within Aotearoa New Zealand have been experimenting with doing academic practices differently, through collective actions premised on an ethic of care (Community Economies Collective et al. 2017; Puawai et al. forthcoming), connecting bodies and materials to thread migrant women’s identities and solidarities (Palomino-Schalscha, Kindon and Guiloff 2016), through community-university partnerships to support refugee resettlement (Collie et al. 2010; Gibson and Kindon 2013; Kale and Kindon 2016), and by developing strategies to support slow and care-full scholarship (Le Heron et al. 2016). Others, like Sophie Bond and Sara Kindon, are involved in different international writing collectives that seek to subvert the calculative management that disciplines academic bodies and creates pressure and precarity while also supporting early career scholars within the neoliberal university (see mrs kinpaisby 2008; mrs c kinpaisby-hill 2011; The SIGJ2 Collective 2012; Tim-adical Collective 2017). There is an excitement about these new perspectives on the politics of bodies, care-work, and collectives as they overtly focus on feminist practice and interventions in addition to conventional and formal publications.

\section{Third moment: Politics of Difference}

The intersectionality of gender, class, race, ethnicity, indigeneity and sexuality reproduce forms of marginalisation globally and in Aotearoa New Zealand. In the last twenty years, the politics of difference has played out in our treaty settlement processes, whereby iwi (Māori tribes) and the Crown settle breaches of the 1840 Te Tiriti o Waitangi (The Treaty of Waitangi) which guaranteed Māori self-governance and - in the Māori language version - sovereignty. Breaches, unsurprisingly, involved the greed of successive colonial governments for more land, and the ongoing discrimination and oppression of Māori that enabled these breach transactions and outright land grabbing. Generations of Māori activists and scholars have sought to speak, write 
and act into this space, and slowly, many Pākēha are coming to fully realise and accept the implications of this systematic abuse of the treaty provisions. Intersectional framing is palpable with concepts of mana wahine (Māori women’s discourses and approaches) (Fisher 2015; Simmonds 2011) and mātauranga Māori (Māori knowledges) (Tuhiwai-Smith 1999).

Feminist geographers here are keenly aware of inclusive practices which enable all voices to be heard on their own terms. For scholars of Māori and Pacific heritage, feminist geographies are intertwined in anti- and de-colonizing projects to (re)assert knowledges, practices, and subjectivities rendered largely invisible through colonization. At Waikato University | Te Whare Wānanga o Waikato, the mana wahine approach is part of a first year geography paper and a complete stream of teaching is based on Māori knowledges. In a third-year course at Victoria University of Wellington | Te Whare Wānanga o Te Ūpoko o Te Ika a Māui, both kaupapa Māori (Māori approaches to knowledge) and mana wahine are integrated alongside feminist, queer and postcolonial theories to examine development both here and overseas. Such pedagogy signals the emergence and value of new feminist Māori scholars (Modlik and Johnston 2017; Ringham, Simmonds and Johnston 2016; Simmonds 2011) who can inform geography teaching. Māori geographies have also gained strong institutional support in several contemporary University spaces and practices. At the University of Canterbury $\mid$ Te Whare Wãnanga o Waitaha, bicultural competency is built into the graduate attributes and the university is working with the local iwi (tribe) of Ngāi Tahu to educate both staff and students on local Māori governance in the university. While resistance to this measure has been expressed sporadically, it is generally because it has not gone far enough and runs the risk of tokenism. 
The challenge is for feminist geographers in the university to act in solidarity with all those who face exclusion. The fundamental partnership of Te Tiriti (The Treaty of Waitangi) makes it possible to work in solidarity with women's movements, Māori activism, queer politics, Pacific and multicultural community members, environmental movements and more. Indeed, feminist geography is rooted in a commitment to representing the voices, bodies and politics of those who are silenced, ignored, violated, or oppressed in one way or another. In Aotearoa New Zealand, many of us take this commitment seriously in our research, building on Doreen Massey's ideas of engaged feminist scholarship as ‘being the struggle’ (Bond and Kindon 2012). Our solidarities are visible in queer geographies (Johnston 2012; Burford and Kindon 2015), Indigenous-nonIndigenous collaborations (Kindon 2012), tangata whenua (Simmonds 2017), inclusivity and intersectionality (Sharp et al. 2017; Spiers et al. 2017), Pacific feminisms (Underhill-Sem 2016), environmental activism and climate justice (Diprose et al. 2017) and youth geographies (Bartos 2012, 2013a, 2013b; Ergler 2017; Gibson and Kindon 2013; Pain et al. 2010; Wood 2013, 2016). Finally, Robyn Longhurst (2008), Naomi Simmonds (2016), Kelly Dombroski (2011) and Yvonne Underhill-Sem $(2001,2016)$ have contributed to Aotearoa New Zealand's strength in feminist geographies of maternity based on their differently positioned lived experiences as Māori, Pākēha and Cook Islander working in Aotearoa, Australia, China, and the Pacific produces three distinctive expressions of the politics of difference. A focus on these particular kinds of bodies throws into sharp relief other sorts of bodies which have yet to attract the specific research interests of feminist geographers.

\section{Fourth moment: Politics of Technology and Time}

With the amplification of previously marginalised voices, another wave of feminist thinking is discernible in Aotearoa New Zealand - one that invites careful consideration of new spaces over 
new dimensions of time. Some of these voices are not just human: the Whanganui river, the ancestor of local iwi, was recently legally declared a person with all the rights and responsibilities this might entail. The ways in which the 'more-than-human’ interacts and enables different forms of collective action in different kinds of spaces is becoming clearer (Thomas 2015). The virtual space of the internet allows for the flourishing of the "call-out” culture which can challenge sexism, misogyny and racism (see also McLean and Maalsen, 2013; McLean, Maalsen and Grech, 2016). Youth participation in social media is shifting politics. The \#metoo campaign made a visible presence as did mobilisation for a Women’s March. On the other hand, the roastbusters' scandal that involved a group of young men who boasted on internet that they purposely intoxicated underage girls and then raped them, highlights the ways in which social media continues to be used to enculturate and normalise sexual violence against women (see also Bartos 2018).

Theorising these new techno-feminisms (and their nemeses) is a space beginning to be taken up by feminist geographers in Aotearoa. Theorising the growing connections between new materialist/science and technology studies with feminist thinking and writing internationally has made its mark here. Kelly Dombroski’s $(2016,2018)$ work on hybrid activist collectives here and in Australia grapples with the materiality of online communities involved in social change work. Jo Waitoa, Regina Scheyvens and Te Rina Warren’s (2015) work on Māori political participation takes seriously the forms of activism that social media enables outside the formal political framework. Rebecca Kiddle et al. (2017) work on imagining a decolonialised city actively engages contemporary social media and youth as part of an action research strategy, while also extending this space into thinking about indigeneity, place and time. The recovery of indigenous 
research in Aotearoa has political synergies with feminist geography. Kindon's work with the iwi of Ngāti Hauiti, for example, has questioned the racialised grammar and Hollywood media conventions at work within many uses of video technology in participatory research (2012, 2016a and 2016b). As a result the spaces of other worldviews become more evident (Simmonds and Gabel 2016; Underhill-Sem 2015). These worldviews treat space and time and culture in ways that can innovatively expand ways of knowing in many dimensions. And, these are the dimensions that are required to understand how to address wider issues of global concern of the Anthropocene (Diprose et al. 2017; Roelvink 2015; Sepie 2017; Underhill-Sem 2015). Many of us in our network are indeed involved in collectives actively working for change in the specific places we find ourselves (Cave et al. 2012) and other techno-activist groups internationally and nationally; some of these groups meet and coordinate via our nationwide university videoconferencing system and the national online portal for social science, eSocSci.

\section{Conclusion}

The impact of nine years of conservative national politics has meant many geography programmes and/or departments across Aotearoa New Zealand are often funded through and supported by science. Social science is marginalised, and within that broad area, feminist geographies even further. Increased precarity in the academy and its detrimental impacts has furthered the ambiguous relationship many have to the notion of "feminism" (Johnston 2017; Peake 2015). Yet as our analysis of feminist moments above demonstrates, there is a progression of research and teaching that is inclusive, expansive and capable of making meaningful differences, and national politics is shifting. Māori geographies, more-than-human geographies and geographies of the body offer exciting possibilities - but this is moderated by contractions in 
social science funding as science, technology and engineering subjects find great political and economic favour, and sadly the fact that very few feminist geographers are gendered male. However, the existence of networked group of like-minded geographers, such as WGGRN, who come together in support and mentorship across all career levels is promising. Closer engagement with feminist scholars in associated disciplines in Aotearoa and abroad is also crucial.

\section{References}

Adams-Hutcheson, Gail. 2015. "Voices in the margins of recovery: relocated Cantabrians in Waikato”. Kotuitui: New Zealand Journal of Social Sciences Online, 10(2): 135-143.

Adams-Hutcheson, Gail. 2017a. "Spatialising skin: Pushing the boundaries of trauma geographies.” Emotion, Space and Society 24: 105-112.

Adams-Hutcheson, Gail. 2017b. "Mobilising research ethics: Two examples from Aotearoa New Zealand.” New Zealand Geographer 73(2): 87-96.

Adams-Hutcheson, Gail. 2017c. Embodied vibrations: disastrous mobilities in relocation from the Christchurch earthquakes, Aotearoa New Zealand. Transfers 7(3): 23-37.

Adams-Hutcheson, Gail. 2018. “Challenging the masculinist framing of disaster research.” Gender, Place \& Culture: A Journal of Feminist Geography 25(1): 149-153.

Adams-Hutcheson, Gail and Robyn Longhurst. 2017. "I'm here, I hate it and I can't cope anymore": Writing about suicide. In P. Moss, \& C. Donovan (Eds.) Writing Intimacy into Feminist Geography (pp. 200-300). Routledge.

Bargh, Maria. 2011. “The triumph of Māori entrepreneurs or diverse economies?” Aboriginal Policy Studies 1(3): 53-69. 
Bargh, Maria and Jacob Otter. 2009. "Progressive spaces of neoliberalism in Aotearoa: A genealogy and critique.” Asia Pacific Viewpoint 50: 154-165.

Bartos, Ann. E. 2012. “Children caring for their worlds: The politics of care and childhood.” Political Geography 31(3): 157-166.

Bartos, Ann. E. 2013a. “Children sensing place.” Emotion, Space and Society 9: 89-98.

Bartos, Ann. E. 2013b. “Friendship and environmental politics in childhood.” Space and Polity 17(1): 17-32.

Bartos, Ann. E. 2017. “The body eating its food politics: Reflections on relationalities and embodied ways of knowing.” Gender, Place \& Culture: A Journal of Feminist Geography 24(2): 153-159.

Bartos, Ann. E. 2018. “The uncomfortable politics of care and conflict: Exploring nontraditional caring agencies.” Geoforum 88: 66-73.

Basnet, Sunila. 2016. “Experiences and the embodied practices of Bhutanese-New Zealander teenage women: Young bodies, going out and sexual practices.” New Zealand Geographer 72(3): 240-249.

Bond, Sophie and Sara Kindon. 2012. "Working with Doreen Downunder: Antipodean trajectories.” In Spatial politics: Essays for Doreen Massey, edited by D. Featherstone and J. Painter, 191-203, London: Wiley-Blackwell.

Bond, Sophie, Gradon Diprose and Amanda Thomas. 2017. Seeking climate justice: Findings report on oil free activism and oil and gar developments 2013-2016. Wellington, New Zealand. 
Bracewell-Worrall, Anna. 2017. "Baby sits on speaker’s lap as paid Parental leave discussed in NZ Parliament,” $9^{\text {th }}$ November, Newshub, http://www.newshub.co.nz/home/politics/2017/11/baby-sits-on-speaker-s-lap-as-paidparental-leave-discussed-in-nz-parliament.html accessed 9th December 2017.

Burford, James and Sara Kindon. 2015 “Queering accounts of MSM practitioner agency: recognising collateral benefits”. Development in Practice, 25(2): 145-159.

Burry, Kate and Polly Stupples. 2017. “'I stap long blad' ('It’s in the blood'): Sex work, agency, and sexual and reproductive rights in Vanuatu”. Women's Studies Journal 31(2): 97-112.

Cave, Jenny, Lynda Johnston, Cary-Anne Morrison and Yvonne Underhill-Sem. 2012. "Community-university collaborations: creating hybrid research and collective identities.” Kotuitui: New Zealand Journal of Social Sciences 7(1): 37-50.

Community Economies Collective, JK Gibson-Graham, Jenny Cameron, Kelly Dombroski, Stephen Healy and Ethan Miller. 2017. “Cultivating Community Economies: Tools for building a liveable world.” In The Next System Project, edited by G Alperovitz and JG Speth. Retrieved at: http://thenextsystem.org/cultivating-community-economies/

Collie, Phillippa, Sara Kindon, James Liu and Astrid Podsiadlowski. 2010. "Mindful identity negotiations: The acculturation of young Assyrian women in New Zealand”, International Journal of Intercultural Relations, 34, 208-220.

Davies, Kate, Emma Sharp, Roseanne Spiers, Karen Fisher and Erena Le Heron. 2016. “Gendered geographies and academic work” panel at New Zealand Geographical Society Conference, Dunedin, 1- 4 February.

Diprose, Gradon. 2015. "Negotiating contradiction: work, redundancy and participatory art.” Area 47: 246-253. 
Diprose, Gradon. 2016. "Negotiating interdependence and anxiety in community economies.” Environment and Planning A 48(7): 1411-1427.

Diprose, Gradon. 2017. "Radical equality, care and labour in a community economy.” Gender, Place \& Culture: A Journal of Feminist Geography 24: 834-850.

Diprose, Gradon, Amanda Thomas and Sophie Bond. 2016. “'It’s who we are’: eco-nationalism and place in contesting deep-sea oil in Aotearoa New Zealand.” Kötuitui New Zealand Journal of Social Sciences Online 11(2): 159-173.

Diprose, Gradon, Kelly Dombroski, Stephen Healy and Joanne Waitoa. 2017a. “Community economies: Responding to questions of scale, agency, and indigenous connections in Aotearoa New Zealand.” Counterfutures 4: 167-184.

Diprose, Gradon, Sophie Bond, Amanda Thomas, Jule Barth and Heather Urquhart. 2017b. “The violence of (in)action: communities, climate and business-as-usual.” Community Development Journal 52(3): 488.

Dombroski, Kelly. 2011. “Awkward engagements in mothering: Embodying and experimenting in northwest China.” In An Anthropology of Mothering, edited by M. Walks \& N. McPherson, 49-66. Toronto: Demeter Press.

Dombroski, Kelly. 2016a. "Hybrid activist collectives: Reframing mothers' environmental and caring labour.” International Journal of Sociology and Social Policy 36(9/10): 629-646.

Dombroski, Kelly. 2016b. "Seeing diversity, multiplying possibility: My journey from post feminism to postdevelopment with JK Gibson-Graham.” In The Palgrave Handbook of Gender and Development, edited by W. Harcourt, 312-328. Basingstoke: Palgrave Macmillan. 
Dombroski, Kelly. 2018. "Learning to be affected: Maternal connection, intuition and “elimination communication”. Emotion, Space and Society. 26:72-79. DOI: 10.1016/j.emospa.2017.09.004

Dombroski, Kelly, Katharine McKinnon and Stephen Healy. 2016. "Beyond the birth wars: Diverse assemblages of care.” New Zealand Geographer 72: 230-239.

Dombroski Kelly, Alison Watkins, Helen Fitt, Jillian Frater, Karen Banwell, Kierin Mackenzie, Levi Mutambo, Kerryn Hawke, Frans Persendt and Jasna Turković. 2018. “Journeying from "I" to "we": assembling hybrid caring collectives of geography doctoral scholars." Journal of Geography in Higher Education. 42(1): 80-93.

Ergler, Christine. 2017. “Advocating for a more relational and dynamic model of participation for child researchers.” Social Inclusion 5(3), 240-250.

Fisher, Karen. 2015. "Positionality, subjectivity, and race in transnational and transcultural geographical research”. Gender, Place \& Culture: A Journal of Feminist Geography 22: 456-473.

Gibson, Stephanie and Sara Kindon. 2013. “Co-creating the museum with refugee-background youth in Aotearoa New Zealand”. Tuhinga, 24, 65-83.

Gibson-Graham, J.K. 2005. “Building community economies: women and the politics of place.” In Women and the Politics of Place, edited by W. Harcourt and A. Escobar, 130-157. Bloomfield, CT: Kumarian Press.

Higgins Vaughan and Wendy Larner 2017. Assembling Neoliberalism. New York: Palgrave Macmillan. 
Hutcheson, Gail. 2013. Methodological reflections on transference and countertransference in geographical research: relocation experiences from post-disaster Christchurch, Aotearoa New Zealand. Area, 45(4): 477-484.

Jacob, Krista and Adela C. Licona. 2005. "Writing the waves: A dialogue on the tools, tactics, and tensions of feminisms and feminist practices over time and place.” NWSA Journal 17(1): 197-205.

Johnston, Lynda. 2005. Queering tourism: Paradoxical performances at gay pride parades. London: Routledge.

Johnston, Lynda. 2012. "Sites of excess: The spatial politics of touch for drag queens in Aotearoa New Zealand.” Emotion, Space and Society 5(1): 1-9.

Johnston, Lynda. 2017. “Gender and sexuality III: Precarious places.” Progress in Human Geography. Advance view online. DOI: 10.1177/0309132517731256.

Johnston, Lynda. 2018 Transforming Gender, Sex, and Place: Gender Variant Geographies, Routledge, London.

Johnston, Lynda and Robyn Longhurst. 2008. “Queer(ing) geographies ‘down under’: some notes on sexuality and space in Australasia.” Australian Geographer 39 (3): 247 - 257.

Johnston, Lynda and Robyn Longhurst. 2010. Space, place and sex: Geographies of sexualities. Lanham, Maryland: Rowman and Littlefield.

Kale, Amber and Sara Kindon. 2016. “'Turning the curve’: Refugee Women Drive Programme Evaluation Report”, prepared for the Good Shepherd Trust, Wellington, Victoria University of Wellington | Te Whare Wānanga o Te Ūpoko o Te Ika a Mãui.

Kallio, Kirsi P. and Ann E. Bartos. 2017. “Children’s caring agencies.” Political Geography, 58: 148-150.

Kelsey, Jane. 1997. The New Zealand experiment. A world model for structural adjustment? 
(2nd Edition). Auckland: Auckland University Press.

Kiddle, Rebecca, Amanda Thomas, Biana Elkington, Jasmine Arthur, Jennie Smeaton, Ocean Mercier, Mike Ross, Morten Gjerde and Derek Kawiti. 2017. “Imagining the decolonised city in Aotearoa/ New Zealand.” In Social movements, resistance and social change 2017: Beyond capitalism, beyond colonisation, Kawhawhai tonu mätou. Oral presentation, 5 September 2017, Massey University | Te Kunenga ki Pūrehuroa, Albany, Auckland.

Kindon, Sara. 2012. “"Thinking-through-Complicity” with Te Iwi o Ngaati Hauiti: Towards a Critical Use of Participatory Video for Research.” PhD Thesis, University of Waikato | Te Whare Wānanga o Waikato, Hamilton, New Zealand.

Kindon, Sara. 2016a. "Participatory video as a feminist practice of looking: 'take two!'.” Area 48: 496-503.

Kindon, Sara. 2016b. “Participatory video’s spectro-geographies, Commentary.” Area 48: 449451.Kindon, S., and Broome, A. 2008. “Creating a space for parents’ voices: Methodological reflections on research about early childhood education and needs with parents from migrant and former refugee backgrounds”. Social Policy Journal of New Zealand, 35, 139-151.

Larner, Wendy. 2000. “Neo-liberalism policy, ideology, governmentality.” Studies in Political Economy 63(1): 5-25.

Le Heron, Erena, Karen Fisher, Emma Sharp, Roseanne Spier and Kate Davies. 2016 “Gender and the academy: slow scholarship in the neoliberal university”. Session presented at the Women Gender Geography Research Network (WGGRN) Symposium, Wellington, New Zealand, 24 June.

Longhurst, Robyn. 2017. Skype: Bodies, screens, space. United Kingdom: Routledge. 
Longhurst, Robyn and Lynda Johnston. 2015. “Contemporary feminist thought in Aotearoa/New Zealand: Recollecting and reflecting on feminist geography in Aotearoa/New Zealand and beyond.” Women’s Studies Journal, 29(1): 21-33.

Longhurst, Robyn. 2001. Bodies: exploring fluid boundaries (1st ed.). London: Routledge.

Longhurst, Robyn. 2008. Maternities: Gender, Bodies and Space. New York: Routledge.

Longhurst, Robyn and Lynda Johnston. 2014. "Bodies, gender, place and culture: 21 years on.” Gender, Place \& Culture: A Journal of feminist Geography 21(3): 267-278.

Longhurst, Robyn, Lynda Johnston and Elsie Ho. 2009. “A visceral approach: cooking 'at home’ with migrant women in Hamilton, New Zealand.” Transactions of the Institute of British Geographers 34: 333-345.

McLean, Jessica and Sophia Maalsen. 2013. "Destroying the joint and dying of shame? A geography of revitalised feminism in social media and beyond.” Geographical Research 51(3): 243-256.

McLean, Jessica, Sophia Maalsen and Alana Grech. 2016. “Learning about feminism in digital spaces: Online methodologies and participatory mapping.” Australian Geographer 47(2): 157-177.

Modlik, Melanie and Lynda Johnston. 2017. "Huhu grubs, bull semen shots and koki: Visceral geographies of regional food festivals in Aotearoa.” New Zealand Geographer 73(1): 2534.

mrs kinpaisby. 2008. “Taking stock of participatory geographies: envisioning the communiversity.” Transactions of the Institute of British Geographers 33(3): 292-299. 
mrs c kinpaisby-hill. 2011. "Participatory praxis and social justice: Towards more fully social geographies.” In a Companion to Social Geography, edited by V. Del Casino, M. Thomas, P. Cloke and R. Panelli, 214-234, London: Blackwell.

Pain, Rachel, Ruth Panelli, Sara Kindon and Jo Little. 2010. "Moments in everyday/distant geopolitics of hope and fear: young people in the UK and New Zealand.” Geoforum, 41, 972-982.

Palomino-Schalscha, Marcela, Sara Kindon and Kirsten Guiloff. 2016. "Latin American women stitching memories and lives in Wellington, Aotearoa New Zealand.” In Itsasoratze artibista. Arterapia eta artibismoa - La embarcada artivista. Arterapia y artivisimo, edited by I. Momoitio Astorkia, Gernika: Fundación Museo de la Paz de Gernika, Gernika Gogoratuz. https://issuu.com/museodelapazdegernika/docs/embarcada_itsasoratze_artibista accessed December 15, 2017.

Peake, Linda. 2015. "The Suzanne Mackenzie Memorial Lecture: Rethinking the politics of feminist knowledge production in Anglo-American geography." The Canadian Geographer/Le Géographe Canadien 59(3): 257-266.

Pihama, Leoni. 2017. “Māori, woman, mother: \#IamMetiria.” Kaupapa Māori as Transformative Indigenous Analysis, blog post on August $9^{\text {th }}$. https://leoniepihama.wordpress.com/2017/08/09/Māori-woman-mother-iammetiria/ accessed December 15, 2017.

Puawai Collective with Davies, Kate, Karen Fisher, Erena Le Heron, Emma Sharp and Roseanne Spiers. Forthcoming. “Assembling Disruptive Practice in the Neoliberal University: an Ethic of Care”. Geografiska Annaler B Special Issue: Early-career women in geography. Practical pathways to advancement in the neoliberal university. 
Ringham, Sandy, Naomi Simmonds and Lynda Johnston. 2016. “Māori tourism geographies: Values, morals and shifting tourism terrains.” MAI Journal 5(2): 99-112.

Roelvink, Gerda. 2015. "Learning to be affected by earth others.” In Manifesto for Living in the Anthropocene, edited by K. Gibson, D. B. Rose \& R. Fincher, 57-62. Brooklyn: Punctum Books.

Scott, Lisa. 2017. "You can’t keep a good woman down.” Otago Daily Times Weekend Mix, Saturday $19^{\text {th }}$ August, p3.

Sepie, Amba. 2017. "More than stories, more than myths: Animal/Human/Nature(s) in traditional ecological worldviews.” Humanities. DOI: 10.3390/h6040078.

Sharp, Emma. 2018. "Enacting other foodworlds: Affective food initiatives performing a carefull politics of difference.” PhD thesis, University of Auckland | Te Whare Wānanga o Tāmaki Makaurau, Auckland, New Zealand.

Sharp, Emma, Roseanne Spiers, Erena Le Heron, Sandy Lee, Karen Fisher and Kelly Bingham. 2017. "Engendering and enabling diverse attendance and participation at academic meetings: A day of co-learning and co-producing knowledge.” Faculty of Science Equity Grant Workshop, 7 November, University of Auckland | Te Whare Wānanga o Tāmaki Makaurau, Auckland, New Zealand.

SIGJ2 Writing Collective. 2012. "What can we do? The challenge of being academics in neoliberal universities.” Antipode: A Radical Journal of Geography 44(4):1055-1058.

Simmonds, Naomi. 2017. "Honouring our ancestors: Reclaiming the power of Māori maternities.” In Indigenous Experiences of Pregnancy and Birth, edited by H. Tait Neufeld, \& J. Cidro, 111-128. Ontario, Canada: Demeter Press. 
Simmonds, Naomi. 2016. “Transformative maternities: Indigenous stories as resistance and reclamation in Aotearoa New Zealand.” In Everyday Knowledge, Education and Sustainable Futures: Transdisciplinary Research in the Asia/Pacific Region, edited by M. Robertson, and P. Tsang, (Vol. 30, pp. 71-88). Singapore: Springer.

Simmonds, Naomi and Kirsten Gabel. 2016. “Ūkaipō: Decolonisation and Māori maternities.” In Decolonisation in Aotearoa: Education, Research and Practice, edited by J. Hutchings, \& J. Lee-Morgan, 145-157. Wellington, New Zealand: NZCER Press.

Simmonds, Naomi. 2011. "Mana Wahine: Decolonising politics.” Women's Studies Journal 25(2): $11-25$

Smolovic-Jones, Sanela, Kate Boocock and Yvonne Underhill-Sem. 2013. ““[PDF] beinghaRasseD?' Accessing Information about Sexual Harassment in New Zealand's Universities.” Women's Studies Association of NZ 27(2):36-48.

Spiers, Roseanna, Emma Sharp, Karen Fisher, Karen Davies and Erena Le Heron. 2017. “Auckland Women and Gender Geographies Research Network Symposium: Review of the Day”, New Zealand Geographical Society, http://www.nzgs.co.nz/nzgs-studygroups/women-and-gender-geographies-study-group, accessed 30 November 2017.

Timadical Collective. 2017. "Vulnerabilities, complicities and injustices: ‘Tim-adical’ actions for change in the neoliberal academy.” Ephemera 17(3)691

Thomas, Amanda. 2015. "Indigenous more-than-humanisms: relational ethics with the Hurunui River in Aotearoa New Zealand.” Social and Cultural Geography 16(8): 974-990. 
Thomas, Amanda and Sophie Bond. 2016. "Reregulating Freshwater Enclosure: a State of Exception in Canterbury, Aotearoa New Zealand.” Antipode: A Radical Journal of Geography 48(3): 770-789.

Tuhiwai Smith, Linda. 1999. Decolonizing methodologies: research and indigenous peoples. London \& New York, Dunedin: Zed Books \& University of Otago Press.

Underhill-Sem Yvonne. 2001. "Maternities in 'out-of-the-way places’: epistemological possibilities for retheorising population geography.” International Journal of Population Geography 7: 47-460.

Underhill-Sem, Yvonne. 2003. "Marked bodies in marginalized places: Understanding rationalities in global discourses." Development 46 (2): 13-17.

Underhill-Sem, Yvonne. 2005. “'Bodies in places; places in bodies'.” In Women and the Politics of Place, edited by W. Harcourt and A. Escobar, 20-31. Bloomfield: Kumerian Press, Bloomfield.

Underhill-Sem, Yvonne. 2015. "Silences of the discourse: maternal bodies in out-of-theway places.” In Oceanian journeys and sojourns: home thoughts abroad, edited by J. A. Bennett, 275-292. Dunedin: Otago University Press.

Underhill-Sem, Yvonne. 2016. Gender Research in the Pacific 1994-2014: Beginnings. Suva: Pacific Women Support Unit. Retrieved from http://www.pacificwomen.org/ Underhill-Sem, Yvonne. 2017. “Academic work as radical practice: getting in, creating a space, not giving up.” Geographical Review 55(3): 332-337. 
Underhill-Sem, Yvonne and Nick Lewis. 2008. Asset mapping and Whanau action research: 'New' subjects negotiating the politics of knowledge in Te Rarawa. Asia Pacific Viewpoint, 49(3), 305-317.

Underhill-Sem, Yvonne with Kaita Sem. 2015. ““Tragedies’ in out-of-the-way places: Oceanic interpretations of another scale.” In Feminist Futures: Reimagining Women, Culture and Development, edited by K.-K. Bhavani, J. Foran and P. Kurian, 43-54. London: Zed Books.

Waitoa, Joanne, Regina Scheyvens and Te Rina Warren. 2015. “E-Whanaungatanga: The role of social media in Māori political empowerment.” AlterNative: An International Journal of Indigenous Peoples 11, 45-58.

Watkins, Alison and Karen Fisher. 2016. “Gender, sex, space and place: women and gender geographies in Aotearoa New Zealand”. New Zealand Geographer, 72(3): 226-229.

Wood, Bronwyn E. 2013. "Young people's emotional geographies of citizenship participation: Spatial and relational insights.” Emotion, Space and Society 9: 50-58.

Wood, Bronwyn E. 2016. “Excluded citizens? Participatory research with young people from a 'failing’ school community.” Children's Geographies 14(3): 310-324. 